arise as some ethical barrier in the human case? And even if it does arise, why can we not conduct medical research on humans who are brain dead, anencephalic infants, and the like, where there never will be anything resembling informed consent? If we are told that we must respect humans, what about them are we to respect? Take, for instance, a person fully in the grip of Alzheimer's disease or senile dementia: is it the human shell we are to respect? Why may we not test drugs upon these people? To reply that our religious or cultural tradition does not sanction it is no longer the stopper it once was, since all manner of actions that many regard as capable of justification, from abortion to euthanasia and physicianassisted suicide, now regularly challenge that tradition. In short, hard questions are being asked of many practices that heretofore have been widely regarded as ethically acceptable, and while it may be true that ethically sensitive biomedical research of high quality is possible within established practices, is it possible when many of the very normative principles that underlie those practices themselves come under attack? It is the examination and the defence or rejection of these principles and so the practices based upon them - I do not prejudge the outcome of this activity that seem both central to and imperative for an ethical discussion of animal and human experimentation today.

R G FREY

Bowling Green State University

\section{Reforming Health Care}

Edited by David Seedhouse, Chichester, UK, John Wiley, 1995 242 pages, $£ 16.95$.

In this book, the seventh in a collection written or edited by David Seedhouse, he sets out to explore modern health reforms in depth. His aim is to show that philosophical analysis is essential to cogent health reform. The book is formed from a collection of articles, written by a range of international authors. Most of the articles have already appeared in Health Care Analysis: Fournal of Health Philosophy and Policy, also edited by David Seedhouse.

The book is divided into three sections. The first section consists of comprehensive articles offering an informed view of various health care systems, reforms and associated debates in the USA, the UK, New Zealand, the Netherlands, South Africa and Lithuania. These chapters give a rich insight into the different systems and the rationale and problems surrounding them. They range from discussion of reasons why urgent reforms to the systems within the US are thought to be necessary, to descriptions of difficulties faced in post-socialist Lithuania, where the majority of the population find great difficulty in obtaining a decent minimum of health care. The vast difficulties facing development of a new health care plan in post-apartheid South Africa, where there is evidence of gross racial discrepancies in health care, are also discussed. A separate article on the oft-quoted Oregon experiment is also included in this first section This describes in detail the still evolving attempts by this American state to devise, in consultation with the community, a basic health care package which, by eliminating procedures which are judged to be least beneficial (for example treatment of viral hepatitis and cancers with less than five per cent predicted recovery at five years), can release funds to cover health care costs for the poorest in society, ie those who cannot afford health insurance.

The six chapters in the second section also refer to various health care systems but are devoted to philosophical discussion, with particular reference to social justice. The third section consists of an examination of the ethics of health promotion. The four authors of this section explore issues such as the nature of health, the extent to which individuals can be held responsible for their own health, and the related issue of "victim blaming". Working on the premise that a theory of health is essential if discussions of health policies are to have any real meaning, their aim is to illustrate the features which are essential to any theory of health.

This book is on the whole, clearly written and easily accessible. By examining health systems internationally (although the editor acknowledges by no means comprehensively) a clear picture emerges of the disparate but also common difficulties in creating systems for fair allocation of resources. Justification for the belief in the necessity for philosophical analysis as a base for health policy and reform is well illustrated. As David Seedhouse points out, some of the chapters illustrate very clearly the fact that philosophy and practice can seem worlds apart when it comes to health policies. Yet, he asks, how can a health reformer make cogent changes unless thought has been given to the principles which should guide the practical reform process? Arguments against apartheid for example, must rest on an alternative theory of social justice, and the Oregon experiment is based on the principle that human beings are of equal value.

This book will be of particular value to anybody involved in forming health policy, health care research or health ethics. However, it would also be of interest to any health professional or student interested in exploring the philosophical basis of practical health care.

MARGARET REDDOCH Imperial College Health Service, London SW7

\section{Philosophy, Psychology and Psychiatry}

\section{Edited by A Phillips Griffiths \\ Cambridge, Cambridge University \\ Press, 1994, 243 pages, $£ 13.95$.}

These indeed are exciting times for philosophy and psychiatry, as Fulford remarks in his interesting essay on mind and madness which begins this book. A newly emerging mutual interest, sketched by Fulford, directs philosophers towards psychiatric concepts, categories and practices, and psychiatrists toward the theory, values, metaphysics, epistemology and methodology informing their profession.

The interest of the philosophers is, on reflection, understandable. Anthony Quinton has observed that given their status as experts on rationality - and we might add, on the moral concepts of personal autonomy, and responsibility - the puzzle lies with philosophers who aren't curious about psychopathology, not with those who are (page 5). And the interest of philosophers has been piqued. Several topics with clear relevance for medical, and particularly, psychiatric, ethics, such as personal identity, have recently received the attention of a significant number of philosophers and benefited from philosophical analysis and scholarly 